\title{
PENGENALAN ATRAKTAN MOSQUITO TRAP HERBAL DALAM PENCEGAHAN PENYAKIT DEMAM BERDARAH DENGUE (DBD) DI DUSUN 2, PERUMAHAN INDOGRIYA, KLANGENAN, KABUPATEN CIREBON
}

\author{
Dadan Ramadhan Apriyanto $^{1 *}$, Sri Marfuati², Ruri Eka Maryam Mulyaningsih ${ }^{1}$ \\ ${ }^{I}$ Departemen Parasitologi, Imunologi, dan Mikrobiologi, Fakultas Kedokteran, Universitas Swadaya Gunung Jati, \\ Cirebon, Indonesia \\ ${ }^{2}$ Departemen Farmakologi, Fakultas Kedokteran, Universitas Swadaya Gunung Jati, Cirebon, Indonesia \\ * Penulis Korespondensi : dadanramadhanapriyanto95@gmail.com
}

\begin{abstract}
Abstrak
Penyakit Demam Berdarah Dengue (DBD) merupakan permasalahan kesehatan yang serius di Kabupaten Cirebon, dengan 846 jumlah kasus terjangkit penyakit DBD pada tahun 2019 yang meningkat dari tahun sebelumnya. Dusun 2, RW.006, Perumahan Indogriya, Desa Klangenan, Kecamatan Klangenan, Kabupaten Cirebon merupakan salah satu wilayah yang endemis terjangkit Demam Berdarah Dengue (DBD). Program pengabdian kepada masyarakat ini dilakukan sebagai upaya menaggulangi penyakit demam berdarah Dengue (DBD) melalui pemanfaatan herbal diterapkan dengan pembuatan produk atraktan mosquito trap yang bersal dari dari tanaman obat. Pengadaan produk dilakukan oleh warga mitra dengan pendampingan tim pelaksana melibatkan stakeholder. Metode yang digunakan adalah pemberian penyuluhan pencegahan DBD dan pelatihan pembuatan atraktan mosquito trap herbal dalam pencegahan DBD secara langsung secara interaktif. Hasil yang diperoleh dari kegiatan ini adanya antusias dari warga Perumahan Indogriya dalam mengimplementasikan mosquito trap dari bahan alami dan ingin mebudidayakan beberapa tanaman yang sebelumnya delum diketahui manfaatnya untuk pencegahan DBD seperti daun jenu dan juga daun kecubung.
\end{abstract}

Kata kunci: Demam Berdarah Dengue; atraktan mosquito trap herbal; Klangenan.

\begin{abstract}
Dengue Hemorrhagic Fever (DHF) is a serious health problem in Kabupaten Cirebon with the number of DHF cases about 846 in 2019. Dusun 2, RW.006, Indogriya Regency, Klangenan Village is one area endemic with Dengue Hemorrhagic Fever (DHF). This program is carried out as an effort to overcome dengue fever (DHF) through the use of herbs that are applied by making attractant mosquito trap products derived from medicinal plants. The product procurement is carried out by partner citizens with the assistance of the stakeholder involvement implementation team. The method used was extension assistance about DHF and training on making herbal mosquito traps in DHF that was sponsored directly interactively. The results obtained from this activity were the enthusiasm of the residents of Indogriya Housing in implementing mosquito traps from natural materials and wanted to cultivate some plants that had not previously been known for the benefits of DHF prevention such as jenu and kecubung leaves.
\end{abstract}

Keywords: Dengue Hemorrhagic Fever; attractant mosquito trap herbs; Klangenan.

\section{PENDAHULUAN}

Daerah tropis dan subtropis merupakan daerah endemik penyakit Demam Berdarah Dengue (DBD) yang muncul sepanjang tahun, terutama pada saat musim hujan ketika kondisi optimal untuk nyamuk berkembang biak. Penyakit DBD merupakan salah satu masalah kesehatan masyarakat yang utama di Indonesia hingga saat ini. Jumlah penderita dan luas daerah penyebarannya semakin bertambah seiring dengan meningkatnya mobilitas dan kepadatan penduduk. Kementerian Kesehatan RI mencatat jumlah penderita
Demam DBD) di Indonesia pada tahun 2018 sebanyak 65.602 kasus dengan jumlah kematian kematian sebanyak 462 orang (Kemenkes RI, 2018). Kabupaten Cirebon merupakan daerah endemis DBD, pada tahun 2019 hingga minggu ke-22 jumlah kejadian penyakit DBD mencapai 846 kasus, dengan jumlah meninggal karena DBD sebanyak 18 orang yang adanya peningkatan dari tahun 2018 yang hanya berjumlah 11 orang. Salah satu wilayah kasus tertinggi dan terjadi kejadian luar biasa (KLB) di wilayah Dusun 2, RW.006, Perumahan Indogriya, Desa Klangenan, 
Kecamatan Klangenan, Kabupaten Cirebon dengan kasus lebih dari 10 orang yang terjangkit DBD (Dinas Kesehatan Kabupaten Cirebon, 2018).

Penyebaran DBD yang tinggi tersebut dipengaruhi oleh faktor cuaca dan iklim serta musim pancaroba yang cenderung menambah jumlah habitat vektor DBD, sanitasi lingkungan dengan tersedianya tempat perindukan nyamuk betina yaitu tempat yang berisi air jernih diantaranya bak mandi, kaleng bekas dan tempat penampungan air serta adanya tempat diantara dua rumah yang saling berhimpit sehingga tergenangnya air jernih yang terabaikan. Kondisi ini diperburuk dengan rendahnya partisipasi masyarakat dalam pengendalian DBD dikarenakan masih kurangnya pengetahuan, sikap dan tindakan kelompok dan masyarakat dalam penanggulangannya DBD (Kemenkes RI, 2018).

Ketersediaan vaksin dan antivirus yang spesifik terhadap virus Dengue belum memadai untuk pencegahan penyakit DBD saat ini, sehingga upaya penanggulangan DBD tergantung pada pemberantasan nyamuk Aedes aegypti. Pengendalian vektor (nyamuk Aedes aegypti betina) merupakan metode utama saat ini dalam pencegahan DBD, selain itu juga pengendalian larva dengan larvasida menjadi cara pengendalian vektor yang paling efektif. Senyawa-senyawa kimia yang dikandung larvasida saat ini seperti temefos dapat memberikan efek samping adanya resistensi larva Aedes aegypti (Mulyatno dkk, 2012), selain itu juga dapat memicu terjadinya kanker dalam jangka panjang, yang dapat masuk dalam tubuh dan terakumulasi didalamnya (Soonwera \& Phasomkusolsil, 2017). Oleh sebab itu, perlu pendekatan terhadap pengendalian nyamuk dengan menggunakan metode yang tepat (lingkungan, biologi dan kimiawi) yang aman, ramah lingkungan dan juga ekonomis.

Upaya preventif melalui kegiatan penggunaan atraktan mosquito trap yang merupakan perangkap nyamuk dan juga telur nyamuk yang berisikan sesuatu larutan senyawa yang memiliki daya tarik terhadap serangga (nyamuk) baik secara kimiawi maupun visual (Fisik). Atraktan dari bahan kimia berupa senyawa ammonia, $\mathrm{CO}_{2}$, asam laktat, dan asam lemak. Zat tersebut merupakan zat organik dan merupakan hasil dari proses metabolisme makhluk hidup, termasuk manusia. Atraktan fisik dapat berupa getaran, suara, warna, baik warna tempat maupun cahaya. Atraktan dapat digunakan untuk mempengaruhi perilaku, memonitor atau menurunkan populasi nyamuk secara langsung, tanpa menyebabkan cedera bagi binatang lain dan manusia, serta tidak meninggalkan residu pada makanan atau bahan pangan (Ponlawat dkk, 2017).

Atraktan Kimia dalam lethal ovitrap yang berhasil dalam mengontrol Aedes aegypti betina di Australia adalah deltamethrin dan lamdasihalotrin. Namun untuk penggunaan insektisida lamdasihalothrin di Indonesia sebagian besar nyamuk Aedes aegypti telah mengalami resistensi terhadap lamdasihalothrin 0,05\% (Widiarti dkk, 2011). Untuk itu pengendalian secara alami menggunakan atraktan dari bahan nabati atau tanaman merupakan salah satu alternatif pengendalian yang ramah lingkungan, mudah diaplikasikan dan tidak berbahaya bagi musuh alami dan serangga yang menguntungkan. Penggunaan dari tanaman obat memiliki tingkat keamanan yang lebih tinggi dibandingkan dengan racun anorganik. Jenis atraktan alami untuk menarik nyamuk yang sudah diaplikasikan adalah daun jenu, dan daun kecubung (Wibowo \& Astuti, 2015).

\section{BAHAN DAN METODE}

Bahan yang digunakan dalam pengenalan atraktan mosquito trap berasal dari botol plastik bekas air minum $1500 \mathrm{~mL}$, gunting, pemotong (cutter), perekat selotip, air bersih, dan kantong plastik hitam serta tanaman obat dari daun jenu dan daun kecubung. Metode yang digunakan adalah pemberian penyuluhan pencegahan DBD dan pelatihan pembuatan atraktan mosquito trap herbal dalam pencegahan DBD secara langsung secara interaktif. Pembuatan atraktan dari daun jenu dan daun kecubung dengan cara mengerigkan daun kemudian diambil 4 helai daun dicacah dan dilarutkan dengan air bersih sebayak 200 $\mathrm{mL}$.

\section{HASIL DAN PEMBAHASAN}

Hasil yang diperoleh dari kegiatan ini meliputi kegiatan penyuluhan dengan mensosialisasikan pencegahan penyakit DBD yang disebabkan oleh virus Dengue secara umum dan juga pengenalan Atraktan Mosquito Trap Herbal dalam Pencegahan Penyakit Demam Berdarah Dengue (DBD).

Hal-hal yang disampaikan dalam penyuluhan adalah apakah itu DBD, agen apa penyebabnya DBD, gejalagejala terjangkit penyakit DBD, cara-cara pencegahan terjangkitnya DBD dengan $3 \mathrm{M}$ plus (menguras bak mandi, menutup penampungan air, mengubur atau mendaur ulang barang bekas yang dapat menjadi sarang nyamuk, dan plus pencegahan lainnya seperti penggunaan ikan dalam penampungan air, ABATE sasi, pengunaan kelambu, obat oles dan penggunaan mosquito trap).

Selanjutnya dilakukan pelatihan langsung dalam membuat mosquito trap yang mengandung atraktan herbal. Pengenalan atraktan mosquito trap herbal yang dibuat menjadi perangkap nyamuk sederhana menggunakan barang bekas botol plastik yang potong menjadi dua yang diselubungi dengan warna gelap dan berisikan campuran air dengan daun jenu ataupun dengan daun kecubung (Gambar 1).
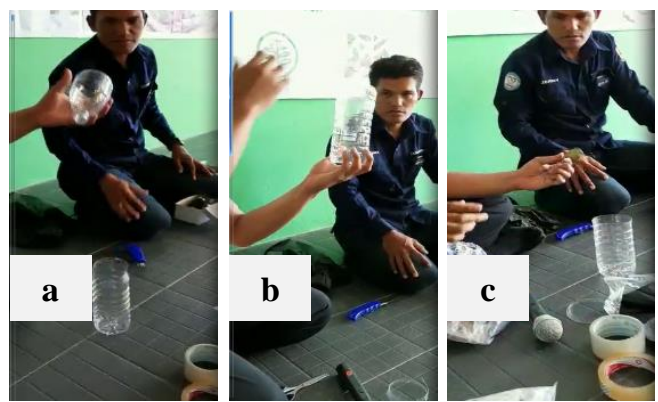

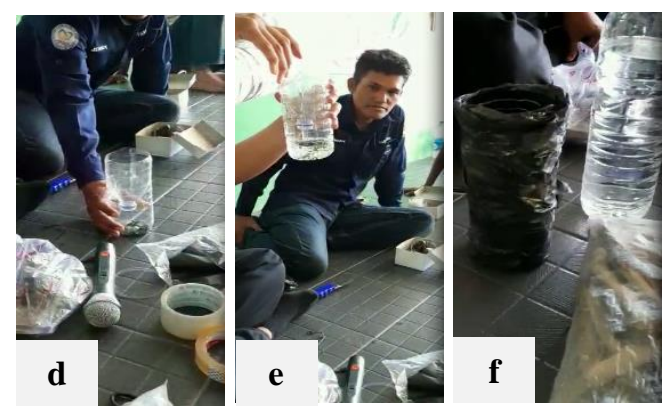

Gambar 1. Proses tahapan pembuatan mosquito trap herbal. (a) botol plastik dibagi menjadi 2 bagian, (b) letakan bagian atas botol kedalam botol bawah, (c) potong-potong 3 helai daun jenu ataupun kecubung dan (d) masukan ke botol, (e) tuangkan air hingga batas tutup botol baian atas diberi ruang sedikit, (f) lapisi dengan plastik hitam dan rekatkan pada botol (mosquto trap).

Berdasarkan hasil pre test tentang penerapan atraktan mosquito trap baik herbal ataupun mosquito trap hanya dengan air didapat hanya $1(4,54 \%)$ responden yang memiliki pengetahuan yang baik tentang penggunaan mosquto trap (tabel 1). Setelah diberikan penyuluhan dan pelatihan adanya peningkatan pengetahuan baik tentang penerapan atraktan mosquito trap baik herbal ataupun mosquito trap hanya dengan air sebesar 18 $(81,82 \%)$ reponden (tabel 1$)$.

Tabel 1. Gambaran tingkat pengetahuan terhadap penerapan atraktan mosquito trap.

\begin{tabular}{ccc}
\hline $\begin{array}{c}\text { Variabel } \\
\text { Pengetahuan }\end{array}$ & Pre-test & Post-test \\
\hline Baik & $1(4,54 \%)$ & $18(81,82 \%)$ \\
Kurang baik & $21(95,45 \%)$ & $3(13,64 \%)$ \\
\hline Total & $\mathbf{2 2 ( 1 0 0 \% )}$ & $\mathbf{2 2 ( 1 0 0 \% )}$ \\
\hline
\end{tabular}

Sesi tanya jawab setelah penyampaian materi penyuluhan, banyak dari warga belum paham agen penyebab DBD yang disebabkan oleh virus, namun warga memahami penyebaran penyakit DBD melalui nyamuk Aedes aegypti dan juga antusias dalam penanggualan penyakit DBD saat perawatan dan pengobatan yang efektif baik secara klinisi dan juga secara alternatif. Pencegahan DBD dari warga Perumahan Indogriya mengeluh saat pencegahan dengan menggunakan fogging, dikarenakan bau dan juga banyaknya perabotan rumah tangga yang agak sulit dibersihkan setelah dilakukan fogging. Setelah dilakukan pelatihan pembuatan atraktan mosquito trap herbal, warga sangat antusias bertanya bagaimana dalam prinsip penggunaan mosquito trap dan atraktan, air apa yang digunakan dan tanaman apa saja yang bisa digunakan sebagai atraktan, tempat peletakan mosquito trap yang baik dan berapa lama penggunaan mosquito trap dan atraktan.

\section{KESIMPULAN}

Pengenalan atraktan mosquito trap baik herbal ataupun mosquito trap dengan air masih terasa asing dalam penerapan teknologi sederhana untuk menanggulangi penyakit DBD di Perumahan Indogriya, Desa Klangenan Kabupaten Cirebon. Perlu penerapan lebih lanjut untuk program mosquito trap baik dapat menggunakan tanaman herbal ataupun tidak untuk mengurangi angka kejadian DBD di Kabupaten Cirebon.

\section{UCAPAN TERIMA KASIH}

Kami ucapankan terima kasih kepada Lembaga Pengabdian Masyarakat Universitas Swadaya Gunung Jati (LPM-UGJ) yang telah memberikan hibah stimulus Program Pengabdian Kepada Masyarakat UGJ. Kepada Kepala Dusun 2, Kepala Kuwu, dan Ketua RW.006 serta pengurus Mushola Baitul Muhajirin yang membantu terlaksannya Kegiatan Program Pengabdian Masyarakat.

\section{DAFTAR PUSTAKA}

Dinas Kesehatan Kabupaten Cirebon. (2018). Profil Kesehatan Dinas Kesehatan kabupaten Cirebon. Dinas Kesehatan Kabupaten Cirebon.

Kemenkes RI. (2018). profil kesehatan 2018.

Mulyatno, K. C., Yamanaka, A., Ngadino, \& Konishi, E. (2012). Resistance of Aedes aegypti (L.) larvae to temephos in Surabaya, Indonesia. Southeast Asian Journal of Tropical Medicine and Public Health, 43(1), 29-33.

Ponlawat, A., Khongtak, P., Jaichapor, B., Pongsiri, A., \& Evans, B. P. (2017). Field evaluation of two commercial mosquito traps baited with different attractants and colored lights for malaria vector surveillance in Thailand. Parasites and Vectors, 10(1), 1-9. https://doi.org/10.1186/s13071-0172315-1

Soonwera, M., \& Phasomkusolsil, S. (2017). Adulticidal, larvicidal, pupicidal and oviposition deterrent activities of essential oil from Zanthoxylum limonella Alston (Rutaceae) against Aedes aegypti (L.) and Culex quinquefasciatus (Say). Asian Pacific Journal of Tropical Biomedicine, 7(11), 967-978. https://doi.org/10.1016/j.apjtb.2017.09.019

Wibowo, S. G., \& Astuti, E. P. (2015). Oviposition Preference of Aedes aegypti Against Various Leaft Extract as an Atractant. Balaba: Jurnal Litbang Pengendalian Penyakit Bersumber Binatang Banjarnegara, 11(1), 23-28. https://doi.org/10.22435/blb.v11i1.4151.23-28

Widiarti, Heriyanto, B., Boewono, D. T., Widyastuti, U., Mujino, Lasmiati, \& Yuliadi. (2011). Peta Resistensi Vektor DBD Aedes aegyti terhadap Insektisida Kelompok Organofosfat, Karbamat, dan Pirethoroid di Provinsi Jateng dan Daerah Istimewa Yogyakarta. Buletin Penelitian Kesehatan, 39(4), 176-189. 